Воленщук Н. А., к.е.н. Донецьька державна сільськогосподарська дослідна станція Національної академії аграрних наук України м. Покровськ, Донецька область, Украӥна

DOI: https://doi.org/10.30525/978-9934-26-028-5-20

\title{
ПРОБЛЕМНІ АСПЕКТИ ВИЗНАЧЕННЯ ЦІНИ ЛЩЕНЗЇ̈ ПРИ ПЕРЕДАЧІ ТЕХОЛОГІЙ
}

Міжнародна торгівля ліцензіями $є$ основним економічним механізмом міжнародного технологічного обміну й наразі набула широкого та швидкого поширення. При купівлі інноваційної продукції за ліцензійним договором, ліцензіат (покупець ліцензії) переслідує економічні та інші вигоди, які планує одержати в конкурентній боротьбі: знизити собівартість продукції, почати випуск нового товару, позбавитись зайвих витрат на власні дослідження, використовувати більш дешевшу сировину чи матеріали [1]. Більшість ліцензійних договорів $є$ комерційними угодами, тому за дозвіл використовувати об'єкт права інтелек- 
туальної власності передбачається сплата певної винагороди, яку називають «ціною ліцензії». Ціну ліцензії визначимо як суму коштів, яку виплачує ліцензіат (покупець ліцензії) продавцю ліцензії - ліцензіару. Сьогодні нагального вирішення набуває проблема визначення ціни ліцензії при передачі технологій, що в свою чергу, тягне за собою розробку методичного інструментарію щодо визначення ставки роялті за відповідними ліцензійними угодами.

Зазвичай, ціну ліцензії встановлює ліцензіар (власник патенту), але при цьому, він повинен орієнтуватись на інтереси та потреби покупця й встановлена ціна має бути заснована на реальній оцінці того економічного ефекту, який отримає покупець від придбаної інноваційної продукції [2]. Спираючись на дослідження М.M. Капіноса, визначимо ціноутворюючі фактори, які впливають на розмір ліцензії (табл. 1).

Світова практика підтверджує вигідність як продажу, так i купівлі ліцензій на використання майнових прав інтелектуальної власності з метою впровадження інновацій (табл. 2).

Незважаючи на те, що механізм ліцензування надає підприємствам широкий спектр можливостей для покращення своєї ринкової позиції, у нього є свої ризики. Тому з точки зору бізнесу, важливо оцінити переваги ліцензування проти його недоліків у порівнянні з іншими альтернативами комерціалізації продуктів і послуг. Ризики механізму ліцензування інтелектуальної власності можуть проявлятися в наступному. Ліцензіат, використовуючи запатентовану технологію чи інноваційний продукт за ліцензійним договором, може стати конкурентом ліцензіара. Діяльність ліцензіата на ринку може привести до зменшення обсягів продажу інноваційного продукту ліцензіаром [3].

Слід відмітити, що на етапі підписання ліцензійного договору ліцензіару й ліцензіату доволі важко оцінити вартість матеріалів, енерговитрат, адміністративні та інші витрати, пов'язані з виробництвом і реалізацією продукції за ліцензією. Наукові установи мереж НААН України, зазвичай, при укладенні ліцензійних угод 
iз ліцензіатами на право вирощування та реалізацію сортів рослин використовують ставки роялті у вигляді відсотків до виручки від реалізації насіння відповідної культури та репродукції. Наприклад, за право вирощування та реалізації насіння ячменю ярого Аверс репродукції еліта ліцензіат повинен сплатити ліцензіару 7\% від загальної виручки від реалізації без врахування податків, а саме ПДВ.

Таблиця 1

Фактори, які впливають на розмір ліцензійної винагороди

\begin{tabular}{|c|c|c|}
\hline \multicolumn{3}{|c|}{ ЦІНОУТВОРЮЮЧІ ФАКТОРИ } \\
\hline Технічні & Економічні & Правові \\
\hline $\begin{array}{c}\text { Ступінь готовності } \\
\text { до впровадження у } \\
\text { виробництво (ідея, } \\
\text { технічне рішення } \\
\text { або промислове } \\
\text { використання) }\end{array}$ & $\begin{array}{c}\text { Розмір очікуваного } \\
\text { прибутку ліцензіата від } \\
\text { використання об’єкта } \\
\text { ліцензії }\end{array}$ & $\begin{array}{c}\text { Вид ліцензії й обсяг } \\
\text { переданих прав }\end{array}$ \\
\hline $\begin{array}{c}\text { Технічна цінність } \\
\text { винаходу або ноу-хау й } \\
\text { можливість їхнього } \\
\text { впровадження }\end{array}$ & $\begin{array}{c}\text { Очікуваний обсяг } \\
\text { випуску ліцензійної } \\
\text { продукції протягом } \\
\text { терміну дії ліцензійної } \\
\text { угоди } \\
\end{array}$ & $\begin{array}{l}\text { Територія дії } \\
\text { ліцензії }\end{array}$ \\
\hline $\begin{array}{c}\text { Можливий ризик } \\
\text { розкриття ноу-хау } \\
\text { конкурентами }\end{array}$ & $\begin{array}{c}\text { Розмір капітальних } \\
\text { вкладень, необхідних } \\
\text { для організації } \\
\text { виробництва ліцензійної } \\
\text { продукції й можливих } \\
\text { джерел їхнього } \\
\text { одержання }\end{array}$ & Строк дії ліцензії \\
\hline $\begin{array}{c}\text { Обсяги технічної } \\
\text { допомоги ліцензіара в } \\
\text { процесі впровадження } \\
\text { об’єкта ліцензії в } \\
\text { виробництво ліцензіата }\end{array}$ & $\begin{array}{c}\text { Результати } \\
\text { маркетингових } \\
\text { досліджень щодо } \\
\text { ємності ринків збуту } \\
\text { ліцензійної продукції в } \\
\text { період дії ліцензії }\end{array}$ & $\begin{array}{c}\text { Державне } \\
\text { регулювання } \\
\text { ліцензійної торгівлі } \\
\text { (розмір роялті, } \\
\text { оподатковування) }\end{array}$ \\
\hline
\end{tabular}

Розглянемо практику визначення ставок роялті в деяких зарубіжних країнах у сфері використання інтелектуальних продуктів за ліцензійними договорами (табл. 3). 
Створення інфраструктури впровадження науково-технічних досягнень у виробництво сприятиме прискоренню комерціалізації інновацій. При цьому важливе місце має встановлення гідних ліцензійних платежів за використання об'єктів права інтелектуальної власності. Комерціалізація інтелектуальної власності - це та рушійна сила, завдяки якій можна активно використати інтелектуальний потенціал України для прискореного інноваційного розвитку економіки [1; 3].

Таблиця 2

\section{Переваги торгівлі ліцензіями для суб'сктів ліцензійного договору}

\begin{tabular}{|c|c|}
\hline $\begin{array}{c}\text { Переваги для ліцензіара } \\
\text { вирішити проблеми при: }\end{array}$ & $\begin{array}{c}\text { Переваги для ліцензіата } \\
\text { дозволяє: }\end{array}$ \\
\hline $\begin{array}{c}\text { раптовому погіршенню } \\
\text { кон'юнктури ринку }\end{array}$ & $\begin{array}{c}\text { освоїти виробництво продукції, що } \\
\text { користується попитом при істотній } \\
\text { економії матеріальних і трудових ресурсів }\end{array}$ \\
\hline $\begin{array}{c}\text { виникнення ускладнень } \\
\text { в експорті товарів через } \\
\text { протекціоністську політику } \\
\text { уряду країни-покупця }\end{array}$ & $\begin{array}{c}\text { підвищити продуктивність праці та } \\
\text { конкурентоспроможність товарів на } \\
\text { зовнішньому ринку }\end{array}$ \\
\hline $\begin{array}{c}\text { значне перевищення попиту } \\
\text { над обсягом власного } \\
\text { виробництва продукції }\end{array}$ & одержати переваги над конкурентами \\
\hline
\end{tabular}

Таблиця 3

Порівняльний аналіз ставок роялті та грошових надходжень зарубіжними селекційними центрами в розрізі країн

\begin{tabular}{|c|c|c|c|c|c|}
\hline Країна & $\begin{array}{c}\text { Вид } \\
\text { ліцензійного } \\
\text { платежу }\end{array}$ & База & $\begin{array}{c}\text { Ставка } \\
\text { роялті }\end{array}$ & $\begin{array}{c}\text { Сплачено } \\
\text { роялті, } \\
\text { млн. дол. }\end{array}$ & $\begin{array}{c}\text { Отримано } \\
\text { роялті, } \\
\text { млн. дол. }\end{array}$ \\
\hline 1 & 2 & 3 & 4 & 5 & 6 \\
\hline Австралія & роялті & $\begin{array}{c}\text { вартість } \\
\text { реалізованого } \\
\text { насіння }\end{array}$ & $\begin{array}{c}3,0- \\
7,5 \%\end{array}$ & 1688,0 & 1365,0 \\
\hline Китай & $\begin{array}{c}\text { поялті } \\
\text { палтістьж } \\
\text { пирощеного } \\
\text { насіння }\end{array}$ & $\begin{array}{c}4,0- \\
11,0 \%\end{array}$ & 3104,0 & 807,0 \\
\hline
\end{tabular}


Продовження Таблиці 3

\begin{tabular}{|c|c|c|c|c|c|}
\hline 1 & 2 & 3 & 4 & 5 & 6 \\
\hline США & роялті & $\begin{array}{c}\text { вартість } \\
\text { вирощеного та } \\
\text { реалізованого } \\
\text { насіння }\end{array}$ & $\begin{array}{c}1,5- \\
15,0 \%\end{array}$ & 8965,0 & 3146,0 \\
\hline Казахстан & $\begin{array}{c}\text { роялті } \\
\text { паушальний } \\
\text { платіж }\end{array}$ & $\begin{array}{c}\text { вартість } \\
\text { вирощеного та } \\
\text { реалізованого } \\
\text { насіння }\end{array}$ & $\begin{array}{c}2,7- \\
9,0 \%\end{array}$ & 1798,0 & 1512,0 \\
\hline
\end{tabular}

Джерело: сформовано на основі [4; 5]

За результатами дослідження встановлено, що визначення ціни ліцензії на сьогодні є одним із найбільш складних етапів передачі технології, тому що комерційна ціна переданого за ліцензією об’єкта інтелектуальної власності може бути визначена лише в процесі його використання в діяльності покупця. Нагального рішення потребує питання розробки та удосконалення методики розрахунку ставок роялті за використання об'єктів права інтелектуальної власності при укладанні договорів трансферу технологій.

\section{Література:}

1. Солощук М.М., Капінос М.М., Лерантович Е.Т. Визначення ціни ліцензії. URL: http://repository.kpi.kharkov.ua/bitstream/KhPI-Press/1366/1/2009_1_Soloshchuk _Vyznachennia_T_10_ch_2.pdf.

2. Капіца Ю.М., Аралова Н.І. Визначення ставок роялті у міжнародних договорах про передачу технологій. Інноваиійна наука. 2015. № 11(2). С. 55-74.

3. Луценко І. Роялті для селекціонерів. АгроБізнес сьогодні. 2013. № 5 (252). C. 11-16.

4. Profitability and royalty rates across industries: Some preliminary evidence URL: https://assets.kpmg.com/content/dam/kpmg/pdf/2015/09/gvi-profitability.pdf.

5. Degnan S., Horton C. A Survey of licensed royalties. Les Nouvelles. 1997. P. 91-96. 